\title{
THE ROLE OF THE SCHOOL PSYCHOLOGIST IN HIGHER EDUCATION
}

AND THE TEACHERS TRAINING

\author{
Kelly Cristina Zavadski \\ Marilda Gonçalves Dias Facci
}

\begin{abstract}
This article aims to discuss issues involving the role of psychologists in the higher education context, based on the assumptions of Cultural Historical Psychology. We point out the possibility of the school psychologist to work in teacher education at this level, observing the contribution to the teacher to understand the development-learning relationship of adults, with emphasis on forming concepts. We also present the results of interviews with 20 teachers from an IES, in 2009, which aimed to analyze the comprehension of the teachers about the development-learning relationship and work of the school psychologist. Concluding, the proposed intervention of Psychology in the teacher education can help teachers to understand how the psychological development is limitless and how the pedagogical activity, in the transmission and acquisition of knowledge, can lead the students to greater development of intellectual ability.
\end{abstract}

Key words: Scholar psychologist work. Higher education. Teacher training. Cultural Historical Psychology

Talking about the role of psychologists in Higher Education is quite complex; if in Basic Education we no longer have clarity on this performance when it comes to intervention in higher education it is even more difficult. One may ask: after all, what is the role of the psychologist in Higher Education? This question motivated the search on the subject whose data is presented in this article. Our 
goal, therefore, is to discuss about the role of psychological professionals in the context of Higher Education, based on the assumptions of Cultural Historical Psychology and emphasizing the importance of the work of the psychologist in training teachers for this level of education.

Marinho-Araújo (2009) states that the School Psychology is already present in HEls (Higher Education Institutions), however, generally, the psychologist is inserted into services that cater exclusively to students (as examples, organs such as the SAU - Assistance Service to the College student - or SOU - Orientation Service to the College student). These services focus on the monitoring of students in the fields of action related to problems of adjustment to college life and new social relations effected; vocational guidance - due to the dissatisfaction with the choice of the course and profession -, or demand related to teaching and learning processes - usually referred by teachers and reported as attention disorders, lack of motivation, lack of adaptation to teaching methodologies proposed and also the emotional problems that interfere with learning. The author also states that this form of intervention is grounded in individual work, adaptationist, so common in Basic Education.

As Marinho-Araújo (2009) asserts a possibility of intervention can be made through broader advice in the context of IES, taking into account characteristics and needs, while observing the intersubjective demands of the subjects involved. It is therefore proposed that the psychologist work encompasses large areas as Public Policy Management, Educational Programs and Processes in HEls; Pedagogical Proposals and Operation of Courses and Student Profile.

Although the author has presented such possibilities of intervention, this study aimed to the proposition of intervention in teacher training, with emphasis on the study of the relationship between development and learning of adults, aiming the importance of this issue for effectiveness of the teacher's work in Higher Education. We are interested in discuss about a performance that strives for human emancipation.

Initially, we will deal on teacher training to work in Higher Education; and in a second step, we will examine the development of the psyche, from the assumptions of Cultural Historical Psychology, and finally we will discuss about the role of the school psychologist in Higher Education.

\section{College teacher training}

The trajectory of the Brazilian Higher Education is recent compared to other countries, since before the arrival of the royal family to 
Brazil in 1808 , it was virtually nonexistent. Until the early 1930 s, training in higher education existed only for professionals. From 1930 until mid1996, according to Marinho-Araujo (2009), the university consolidates as a center - central academic administration figure - of Higher Education in Brazil.

Between 1945 and 1964, the Brazilian Higher Education underwent an intense process of change. According to Saviani (1999), in this period occurred the attempt to implement social changes through the intervention of the State, under the nationalist ideology. The author states that after 1964, the goal of modernization persisted, but there were opportunities to implement it by performing a kind of asepsis of social pressures and conflicts. The educational plan for higher education was designed as a tool for the introduction of technocratic rationality in education, during which it was possible to observe a technical vision of education. Guidelines on Higher Education, in the Law 5540/68, remained until 1996, when, on December $20^{\text {th }}$, was voted the Law of Guidelines and Bases of National Education, number 9394/96, which defines the objectives , priorities and conditions for educational policy. This law and the decree 2207/97, which regulates the Federal Education, discuss the pedagogical preparation for the exercise of teaching in Higher Education. According to the LDB art. 16, the "preparation for the practice of teaching will take place at the graduate programs primarily in master's and doctorate courses" (Law 9394, 1996, p. 7).

In stricto sensu graduate courses, or even in lato sensu graduate courses in general, this preparation has been taking place through a discipline 45-60 hours with different characteristics. Regarding this aspect, Pimenta and Anastasiou (2005, p. 108) report that for many college teachers, this training set as the only possibility of a reflection "on the classroom, the role of teachers, teaching and learning, planning, organization of curriculum content, methodology, teaching techniques, the assessment process, the course and the social reality in which they operate". However, more recent national and international studies show that more effective actions for teacher training occur in continued professionalization processes that involve various elements, intertwining the various understandings of teaching.

Pimenta and Anastasiou (2005) cite that the main topics addressed deal with the knowledge of experience, knowledge of knowledge and pedagogical knowledge, with a view to the pursuit of constructing professional identity, understood as a process of building a contextualized and historically situated professional. This initiative of continuing training, even if not always grounded in the importance of theoretical foundations, still takes first steps.

When analyzed the process of development of higher education in Brazil, Dal Castel (2007) notes that the growth of this education was not accompanied by compatible procedures to provide adequate teacher for- 
mation or subsidies for pedagogical practice. The author argues that, even with so many adverse circumstances and demands of contemporary society, the specific preparation for the teaching is still something unknown.

Emphatically Dal Castel (2007) postulates that improvisation is a general and persistent tonic. The college teacher often learns to play his role in a process of intuitive and self-taught socialization, or following the routine of "others". According to Pimenta and Anastasiou (2005), this is explained by the lack of specific training to work as a college professor. In this process, the teacher follows the paradigm - to a greater or lesser extent - of his own experience as a student.

The training of teachers of higher education is the responsibility of individual and institutional initiatives. Perhaps due to these factors, still prevail in university organization, curricula organized by juxtaposition of disciplines and the figure of the teacher transmitter of curriculum content without worrying about the appropriation of knowledge by students, in the style of traditional Pedagogy. In the analysis of Placco (2006), college professor should consider the multiplicity, particular and collective needs of the student. The author believes that the teacher is not always able to assess the fragmentation of the practice or training, and this condition is often related to the social, political, ethical and/or affective context of the formation and of the environment. These factors influence the formation and action of the teacher and keep the teacher on alienation of himself and work.

Based on a Marxist view of education and teacher training, based on the Historical-Critical Pedagogy, Saviani (1997) addressed the role of the college professor, and stated that this must be linked to the production of knowledge. The author believes that higher education cannot dissociate from the research and, therefore, the teacher at this level of education is a researcher. The teacher produces knowledge and this, in turn, needs to be socialized with the students and the external community. It only makes sense to develop research if the results are appropriate for students because, still according to Saviani, we must be clear that the function of the school is the transmission-acquisition of knowledge by students, regardless of education level.

In the same theoretical line, Mazzeu (1998) says it has been common to analyze these two fields - of student learning and teacher training - separately. For the author, the historical-critical perspective "allows the understanding of student learning as an active process, without disregarding the action of the teacher in this activity" (p. 2). The author emphasizes the need to implement a continuous training that strives for the transmission of knowledge historically accumulated by humanity. However, to this purpose, "to get students to appropriate the school knowledge in order to become independent and critical, the teacher 
needs to take this knowledge and become increasingly autonomous and critical" (p. 2).

Dal Castel (2007) ensures that this matter brings up a dilemma for higher education institutions and teachers, since the pragmatic training take the scene by imposing the maximum useful knowledge, the ability to provide immediate responses to needs of the moment, aiming the satisfaction of the individual and companies. This scenario affects teacher training, since, in this context, the teacher needs to be an excellent listener, and the student is seen as a customer. In this point of view, is broken the idea that the Higher Education Institution is an educational community with the purpose of forming the human being emancipated, i.e. it is thus considered as enough a productive citizen and alienated to the economic system.

For the teacher to break with this view and understand the education as a process of humanization - approach advocated by the Historical-Critical Pedagogy by Dermeval Saviani (Saviani, 2003) - it is necessary to have material conditions for this purpose. Among these conditions, we agree with Dal Castel (2007) when emphasizes the need for initial training of good quality, dignified and appropriate work, career plan, salary motivating and appropriate, consistent with the role, feasibility to participate in professional programs and, above all, time to study. The criticism extends when observed that those conditions are when they are - precariously offered or outsourced to most teachers in Higher Education. This situation is verified without distinction in public or private institutions, once there is an overwhelming tendency of rapid formation, difficulty in wages, accumulation of functions and a growing need for production - that extends beyond the teaching activity in the classroom.

What can be seen today is that the policy of teacher training for higher education is held indirectly. The government determines the parameters of institutional quality and $\mathrm{HEl}$ selects and develops a policy of training the teachers, guided by such parameters. Little investment is made in order to analyze the significance of teaching. In this sense, we understand that the school psychologist could contribute to improve the training of these teachers and in the case of this article we advocate a training supported by the assumptions of Cultural-Historical Psychology. If we start from a conception of development and learning supported by this theory, we understand that it is role of education to aid in promoting the psychological development of the student. Therefore the teacher teaches and leads the student to develop full potential, which is worked on the next item. 


\section{The unlimited development of the human being}

As we proposed to study the development and learning in Higher Education, we understand that this is a process that never runs out. The relationship between education and training of higher psychological processes should be emphasized. Such training occurs with the abstraction of complex concepts that are possible when the learning process accomplishes its characteristic of "boosting" the development. This item explains these aspects.

For Vygotski (2001), the behavior of the "modern, cultural" man would not only be the product of biological evolution, but also from historical development. According to the author, from the fundamentals of dialectical and historical materialism, the historical development of mankind, there have been changes in the relationships between people, in the relationship between man and nature and, therefore, changed human nature itself.

According to Engels (1990), language, as well as the use of other signs, emerged from needs related to development of work. In this sense, Vygotsky and Luria (1996) noted that as man increasingly controls nature over, social and work activities require more high demands to control the behavior. Thus, it is developed varied skills and technical resources within the culture that enable man to ascend to a higher level of behavior. For the development of higher mental functions - such as abstract reasoning, logical memory, abstraction, attention concentrated, for example - it is needed willingness, a mediation of instruments and signs, and that the external environment promotes such development.

Vygotski and Luria (1996, p. 215) highlight that:

The development begins with the mobilization of more primitive (innate) functions, with their natural use. Then goes through a training phase, in which, under the influence of external conditions, it changes its structure and starts to become from a natural process into a complex "cultural process" when it is a new form of behavior with help of a number of external devices. The development finally comes to a stage at which these external auxiliary devices are abandoned and rendered useless and the organism becomes transformed from this evolutionary process, endowed of new forms and techniques of behavior.

Facci (2004a, p. 155), based on Vygotski, explains that the way the man "was interacting in society and with nature led to the need for mediators - the tools and signs - whose utilization characterizes the operation of higher psychological processes. Through the mediation, these functions develop".The signs would be related to psychic functions, and instruments would be the objects that would perform material actions. 
"The sign acts as an instrument of psychological activity, similar to a tool that performs the work" (Vygotski, 2000, p. 88).

Vygotski (2000) asserts that the transition from mediated activity and the use of tools (artificial media) alter all the psychological functions, expanding the range of activities in which they operate these new functions. The inclusion of signs into behavioral processes enables the reorganization of the whole behavior, that is, the whole human consciousness. In addition, Higher Psychological Functions (HPF) are responsible for the external organization of conduct and regulate individual behavior, thus differentiating individuals from animals.

Vygotski (1998) emphasizes that the process of assimilation of the HPF is a series of transformations that runs from the interpsychological level - between people - to the intrapsychological level - at the internalization level. According to Vygotski (1998), this process - undergoing transformation - before being definitely internalized continues to exist and to change as an external form of activity for a long period of time. In some functions, the stage of external signs is maintained, i.e., sets up in the final stage of development. Yet other functions go beyond the development, becoming gradually interior functions.

Vygotski (1998) argues that the internalization of cultural forms of behavior involves the reorganization of psychological activity, based on the operations with signs. Psychological processes in more primitive form cease to exist because they are embedded in a system of behaviors that are culturally reconstructed to create a new psychological "entity". This process is observed in adulthood, when there is the ability to generalize these contents internalized.

The development of HPF is the basis of all conscious experience of the human being and, according to Vygotsky and Luria (1996), this awareness is only possible through thinking in concepts. In forming concepts are merged all basic intellectual functions, and the individual development is improved through communication. According to Facci (2004a), through language occurs the reorganization of the structure of psychological functions and it is from it that processes regulating the actions of human beings are formed.

Development is the process by which the individual actively constructs characteristics from generation to generation. The complexity of the development achieved by a society is accumulated, transmitted to the individual from birth. For the successful performance of this task it is essential to refer to the purpose of the school, it is also through this institution that the child has the opportunity to take ownership of the contents produced by men in the historical process and thus to humanize. We emphasize in this regard the importance of understanding the formation of concepts, which are appropriate by means of education, 
since this aspect is closely related to the development of higher psychological functions.

In Vygotskian perspective, the concepts are understood as a system of relationships and generalization contained in the words and determined by a historical-cultural process: they are cultural constructs, internalized by the individual during its development. The attributes required to define a concept are set by characteristics of the elements found in the real world, selected as relevant by the various cultural groups. It is the cultural group in which the individual develops that will provide the universe of meanings that orders the actual categories (concepts), appointed by the words of the language of that group.

According to Vygotski (2001), the concept emerges during an intellectual operation. It is not the result of simple associations, given the interference of all intellectual forms for its formation, ending in a unique combination with the use of the word. Every concept is a generalization, because, to acquire a new concept, the individual has to report to other concepts that have been already obtained through social relationships. For the author, the appropriation of concepts allows the individual to understand the reality experienced. The process of concept formation involves self-regulation - domain - of psychic processes specific to each individual, which is achieved by the conscious use of signs and words.

Concept formation is linked, in a dialectical relationship, to the development of higher psychological functions. Vygotsky (2001) affirms that the formation of concepts takes place progressively and only in adolescence develops intellectual functions necessary for the transition to conceptual thinking. According to Facci (2004a, p. 157-158) this is because are developed "new and complex combinations of elementary functions by the appearance of several complex syntheses". Several concepts were appropriated in the course of development, causing the overcoming of elementary functions, and a determining factor for the child's intellectual development is the interaction with adults, through communication.

The direct impressions, dominant in the child, give rise to abstractions and generalizations ubiquitous in internal and external speech in the adolescent. Vygotsky when analyzed the fundamental changes in the development of mental processes (changes that express successive forms of reflection of reality), also noted that while the child think through memories, the adolescent remembers through thought. Thus, the construction of complex forms of reflection of reality and activity occurs along with radical changes in mental processes that affect these types of reflection and constitute the substrate of behavior.Vygotsky called this proposition as semantic and systemic structure of awareness. (Luria, 1990, p. 26) 
Communication given through the language determines the formation of self-regulation processes of the human being. By human contact, the individual acquires language, begins to communicate with other human beings and to organize the thinking, i.e., regulates higher psychological processes.

The thinking by concepts opens to the young a reality of social consciousness in which the most diverse knowledge of many areas can be assimilated. With the appropriation of new knowledge accomplished through social relationships - particularly in education - elementary functions that provide concrete thinking are being transformed and overcome, increasingly strengthening abstract thinking. Davidov and Márkova (1987) claim that the study activity serves as a means of professional preparation, once the individual has the cognitive capacity expanded due to the appropriation of various concepts.

It is worth to emphasize the importance of education for the whole process of concept formation to become effective. The scientific concept requires awareness as to what is appropriate, so it needs to be systematized by the teacher. For Vygotsky (2001), forms of intellectual activity typical of adults - conceptual thinking - are embryonically present in children's thinking, but only will be set up and develop in adolescence. Thus, it emphasizes the importance of the environment to challenge, stimulate the intellect of the adolescent. In the case of the school, this stimulus will be realized through the transmission of scientific knowledge.

Vygotski (2001) distinguished the existence of scientific concepts and spontaneous concepts, whose process is intimately interconnected where one influences the other. For the author, spontaneous concepts refer to those concepts constructed from observation, manipulation and direct experience of individuals, allowing the synthesis and generalization of object characteristics (concept) assimilated and distinguish it from other categories. To Nuñes and Pacheco (1997), as well as for Vygotsky, spontaneous concepts are formed in everyday life, through trial and error and based on the common attributes of objects. They are characterized by the absence of perception of the relationships between objects, being guided by concrete similarities and isolated generalizations on the attributes of objects. On the other hand, scientific concepts are related to events not directly accessible to observation or immediate action of the child; consist of systematized knowledge acquired in school interactions. These concepts are more complex and embedded in a conceptual system of gradual abstractions, with different degrees of generalization. 
For Vygotski (2001) and Nuñes and Pacheco (1997), spontaneous concepts represent the base for scientific concepts. "The development of the scientific concept begins by working with the concept itself, by its discursive definition, followed by activities that require the conscious use of the attributes that make up the definition of the concept" (Nuñes \& Pacheco, 1997, p. 21). Once assimilated, scientific concepts enable the spontaneous formation of other concepts that may be used consciously and deliberately.

In agreement with Nuñes and Pacheco (1997), scientific concepts are characterized by being part of a complex hierarchical system, with different levels of organization, subordination and superordination expressed as principles, laws and theories. It also involves mental operations of abstraction and generalization more complex than spontaneous concepts.

According to Vygotski (2001), before an unknown systematized concept, the child seeks its meaning through approach with other concepts already known, already developed and internalized. In this way, according to the author, to take ownership of a concept is required the information received from the outside, an intense mental activity by the individual. Therefore, a scientific concept is not learned through mechanical training and not merely transmitted by the teacher. The conceptual thought is an achievement that depends not only on individual effort, but mainly on the context in which individuals operate. Accordingly, Luria (1990) points out the following:

The conceptual thinking involves a major expansion of the forms resulting from cognitive activity. A person capable of abstract thought reflects the external world more deeply and completely, and reaches conclusions and inferences about perceived phenomenon, based on not only the personal experience, but also the patterns of logical thought that objectively are formed in an advanced stage of development of cognitive activity. (p. 135)

This ability would denote the cognitive evolution of man towards abstracting the surrounding world and thereby interfere punctually with its construction - and we still believe that this (re)construction of the world could be carried out through the work. It is precisely this capacity of abstraction that we mean when considering the individual in adulthood that appropriates knowledge of Higher Education.

In this way, Tolstij (1989) asserts that adulthood in the contemporary world is valued because of expanding time for education and professional preparation, all arising from the requirements of a revolution that the author calls as technical-scientific. For this context takes place, according to the author, the necessity of education continues into adulthood, by the requirement to appropriate knowledge, skills and habits, 
but mainly by the need to renew the reference standards fundamental to professional activity. The appropriation of scientific concepts that would guide this premise is founded in our society, through the Higher Education Institutions - responsible for the transmission of scientific concepts that lead to enhancement of certain professional activities.

According to Leontiev, Luria and Vygotsky (1991), the school, by transmitting scientific knowledge, would be the institution responsible for promoting educational activities that lead to the overcoming of elementary functions and, consequently, the development of higher levels of development. Accordingly, Tuleski (2008) emphasizes that:

The process of cultural and psychic development of child is revolutionary. Once the cultural development of human conduct is a revolutionary product of the medium, it demonstrates how the school might be able to generate this internal revolution, to promote the overcoming of elementary and organic functions by the formation of cultural and higher mental functions. (p. 173)

All the knowledge acquisition process through school processes "drags" the development, so it would be function of school to suggest increasingly complex tasks to the individual and, at the same time provide the cultural resources required for solving thereof. This assumption should guide any level of education, including higher education. However, it is questioned: how the psychologist can contribute to this task?

\section{The role of the psychologist in teacher training}

The purpose of this article, as reported in the introduction, is to discuss about the role of psychology professionals in the field of action of Higher Education. After dealing with the relationship between development and learning of adults, it is necessary to discuss the teachers' understanding of this relationship. For this, we present data from a survey on 20 teachers from a private institution in the southwest region of the Paraná State, in 2009, through semi-structured interviews, with the aim of examining how teachers understand the relationship between development and learning in adults as well the possibilities of the work of a psychologist in training teachers.

In our survey, when teachers were asked about their understanding on the process of development and learning in the adult, we noted that almost half of the responses $-47.8 \%$ - not explicitly stated how the teacher understands this process. Here, we could take up the whole discussion about teacher training for higher education, and the lack of subjects that address this knowledge to construct the meaning of 
teaching. Besides not understanding this relationship, teachers tried to bring an assertion about the process, and related the process of development and learning of adults as a construct provided by the relationship between teacher and student $-17.3 \%$. Or they even neglect the process, without establishing the relationship between development and learning, stating that learning is continuous ( $8.6 \%$ of responses), i.e., they have a fragmented view of a process that occurs simultaneously. Also, the teacher tends to assign the execution of the process of development and learning to the capacity for abstraction of the student ( $8.6 \%$ of responses), which allows perceiving a tendency to blame the individual for the failed teaching process. The teacher comes to be responsible, through its ability to abstract, for establishing relationships that will lead to development through learning.

At this point, we refer to data that point how teachers understand the teaching function, once we got only one response that referred to the role of knowledge mediation. The most frequent responses (28.5\%) did not specify how it should be the work of teachers in higher education; they were only confined to the form of organization of classes. Then we have an understanding of a teacher's facilitation work, linked to a Piaget view (19\%) followed by an interdisciplinary work $(9.5 \%)$, aimed to the objectives of the course (9.5\%) and the specific reality regional and/or institutional.

Besides that, in our research, we noticed that teachers attribute to psychologist three areas of activity: teachers, students and institutions. What strikes us is that in the sample, $49.7 \%$ of responses refer to the work of the psychologist as a support to teacher in various contexts. A specific category with the highest percentage of responses is linked to the work of psychologists, which contribute to the performance of teachers regarding teaching strategies (15.7\%). It is worth noting that teachers cited the importance of the assistance of a psychologist to understand the learning difficulties of students and the challenges of interaction between teachers and students (13\%).

Another issue emphasized by teachers is the collaboration of psychologists in building a professional identity for teachers, acting with motivation, self-knowledge and training, i.e. building, next to the teaching staff, the significance of this practice so neglected in the educational context we experience.

The significance of this practice, in our view, refers to appropriation of knowledge by students, leading to the psychological development thereof. According to Facci (2009), "it is necessary to the teacher understands that, in teaching, it is not 'open drawers' for each subject, as if it alone develops this or that psychological function" (p. 120). As in the previous section, the development of the human being is unlimited. It is this aspect that Higher Education should focus: take the student to 
form new concepts, new objectifications. We agree with the author and we question, then, about what would be the role of the psychologist in this context. Facci (2009) mentions that one possibility would be to rescue along with the teacher - through Vygotskian theory - the relationship between learning and development, emphasizing that the former promotes the development of higher psychological functions. Thus, the author states that it would be given a considerable contribution to the transformation of teaching practices. In this way, one of the possibilities of the psychologist in Higher Education is working in teacher training, especially providing tools about the development process and student learning, since, as observed herein, that understanding of this process hardly occurs. The goal of the work is to take the teacher to understand the possibility to contribute to the process of humanization of students.

In agreement with Tanamachi and Meira (2003, p. 45), the teacher cannot truly teach without considering "how the student learns, or why sometimes the student does not learn." If schools are socializing instances of historically produced and accumulated knowledge and the teaching function is performed in the task of teaching, the authors emphasize the need for the teacher to select both the cultural elements that need to be assimilated by the students (content) and forms appropriate to transmit this knowledge.

For Vygotski (2000), teaching should "pull" the development, which would be equivalent to the redemption of the active role of the teacher in the classroom with regard to the processes of development and learning. According to Tanamachi and Meira (2003), the teacher should not expect students to "mature", as Vygotsky, they defend the idea that education has to be directed to the future, prospectively, investing in the maximum development of potential of learners.

Facci (2004b) argues that it is now possible to glimpse (theoretical) productions and interventions that aim to understand and build an Educational Psychology with Marxist basis. According to the author, this Psychology would aim to "analyze the human psyche from the historicity of all phenomena and consider the educational process due to certain material conditions" (p. 100). Still, the author emphasizes that we would not be trying to establish only criticism, but, above all, seek to advance the understanding of relationships between the development of the psyche and the schooling process. This path would have "the purpose of transforming the vision of man in pedagogical practice, understanding as one whom, having the conscience modified by the appropriation of scientific knowledge, can cause changes in the social practice" (p. 100). This idea, therefore, from our point of view, would guide the work of psychologists in Higher Education.

Therefore, it would be sought to overcome the idea of a school psychologist acting only as a technician, but rather as a mediator who, 
along with everyone involved in the educational process, could critically evaluate educational initiatives and participate - in a collective effort - actively in building a qualitatively superior pedagogical process, which critically comprises the human development process and analyzes the man as a summary of social relationships.

In this way, we can point to a real possibility of accomplishing the performance of psychologists in training of teachers, because in addition to being able to contribute with the specific knowledge, the professional can help break through the barriers that are established in the educational process. We agree with Meira (2003) when stated that the educational psychologist is whom "in his/her limits and specificity can help the school to remove the obstacles between the subject and knowledge, favoring processes of humanization and development of critical thinking" (p. 58).

In the practice of Psychology with teachers, Checchia and Souza (2003) showed that the psychologist should adopt a practice that request the participation of teachers, so that they reflect on their teaching practices, as well as factors related to educational failure. This participation of teachers, according to Checchia and Souza (2003), should be directed to a "discussion of issues related to analysis of pedagogical, institutional aspects and the relationship with the students, as well as emphasis on the development of resources and experiences of teachers" (p. 132).

In our research with teachers, it is seen an expectation of work relative to school failure of students, as $31.4 \%$ of responses consider that the psychologist in Higher Education should be directed to and only to the student. Breaking with this demand implies overcome various institutional obstacles that expect the psychologist, also in Higher Education, work on a clinical view to solve individual problems of students or problems arising from the teacher-student relationship. The work, in addition to teacher training, involves working at the institutional level, seeking to contribute to everyone involved in the school understand school failure as a result of historical and social conditions.

Meira (2003) presents the need to rethink the inclusion of Psychology in teacher training courses, so that psychological knowledge can effectively assist in the formulation of proposals that contribute to the improvement of the teaching-learning process. The author also adds that beyond initial training, Psychology must be present in the field of action of teachers who are already working. It is important to adopt this premise, regardless of education level in which the psychologist is working.

The author mentions the existence of works that focus on Psychology as an input for the teacher to reflect on actions, in contrast with theories available - questioning the practice - in order to recognize what 
theory pervades it." Through the better understanding of the reason of certain actions, the teacher will have more conditions to deliberately seek ways to transform the action" (Meira, 2003, p. 33), including investigating the theoretical knowledge to perform the necessary changes. Nevertheless, it was not observed studies aimed at understanding psychological concepts that might support this practice.

\section{Final considerations}

One of the proposals for the role of School Psychology in Higher Education, in our view, as mentioned at other times, is working in teacher training. In this training, we believe that one of the issues that can be addressed is the psychological development of students in the educational process, focusing mainly on the development in adulthood, given that it is with this age that college teachers deal with. From our point of view, it reinforces one of the positions of Vygotsky (2001), historically defended, about the relationship between Psychology and Pedagogy, which presents the idea that it is up to Psychology to provide basis to Pedagogy, with regard to understanding the processes of development and learning of students.

Of the adult who has acquired conceptual thinking and remains in the educational environment - through Higher Education Institutions - is expected to develop the capacity for abstraction and generalization of increasingly complex contents. Such a development would consequently lead to the practice of critical reflection of the society in which this adult is located, i.e., it is expected that the process of development and learning is fostered and continued, and the adult - in Higher Education - become increasingly less alienated and is able to position himself critically in all social spheres. However, it is important to note that the way we experience education in capitalist society - in which the disciplines at all levels of education, including higher education, are treated and "transferred" in a fragmented way - this critical position by the individual is far from being effected, and is up to this subject to reproduce the alienation by pragmatism.

This reproduction also occurs often with the psychologist who is also formed in the capitalist society and cannot always have a critical view of reality. We cannot dwell on regarding this training, but we know that this professional has a training much more focused on performance in the clinical context than in school, with little knowledge of the educational system. In training, the student is guided by a more positivist view of reality than a training committed to understanding the whole. It is also worth mentioning that training in Psychology is also 
influenced by the current pedagogical trends that value more practical than theoretical knowledge; this fact can affect the way the professional develops the practice in higher education. Psychologists have not always clear that their intervention, regardless of the level of education, should contribute to the socialization of knowledge. This professional also lives often a process of alienation.

The teacher is often in a process of alienation when, in pedagogical activity, he ceases to understanding that the significance of his role is to teach, mediate and foster the development of higher psychological processes via transmission and appropriation of scientific knowledge. The meaning of his work, according to Basso (1998), ends up restricted to the acquisition of objective conditions to meet their basic needs. When there is a rupture between meaning and sense, as stated by Leontiev (1978), there is a process of alienation. In this way, the most visible consequence, when the alienation takes place, is the restriction of the development of the human personality. This because, when individuals sell their labor, eventually distances the sense from the content of their activity and thereby distancing their personality from the work activity. In other words, the work becomes external and alien to the personality when it should actually focus on the process of objectification of the individual's personality. It is appropriate to state that Leontiev (1978) postulates that without the possibility of objectification, the personality becomes restricted and limited in its development

Basso (1998) argued that for a privileged teacher training, we should strive for building new working relationships in school, enabling the collective coping with objective and subjective conditions that arise as obstacles to school learning. Furthermore, it would be necessary to privilege the theoretical-methodological deepening that favors creation.

This debate can be extended by presenting a multitude of arguments and paths, however, we agree with Dal Castel (2007) stressing that:

The teacher needs theoretical foundations that contribute to the analysis of practice is consistent with the framework adopted. It is necessary that the teacher in the educational approach, understands how to teach and how to learn, basing his working methodology on a philosophical and epistemological conception, with which he identifies himself or believe, developing his activity consistently supported by it. (Dal Castel, 2007, p. 251)

Several challenges are established in this context, and according to Martins (2007), new intervention strategies in teacher training come to accomplish that capacity - of rapid adaptation to social changes. Nevertheless, it is important to emphasize that a major challenge to be 
overcome for the construction of a teaching identity that goes beyond the alienation is on building solid pillars of teacher training, surpassing the current trend to shift focus from knowledge to teacher self-knowledge, for a life story, and not for a solid formation, enriched in terms of scientific knowledge that will serve as support for acts in the classroom in order to provoke the emancipation of students.

Considering these points, we can categorically state that we are still far away from a teaching training for higher education that can overcome all these challenges.

Facci (2009) states that the role of school psychologists in training teachers must provide the analysis of man being formed by capitalist society, in contrast to the kind of man that the school wants to build. Our proposal is to think of a man committed to the community.

It is function of education to provide conditions for the appropriation of generic objectifications that lead individuals to the generalization of social activities, culminating in maximum freedom and universal human condition and removing the individual from alienation. Therefore, for the understanding of an intervention of the psychologist in Higher Education, we have to be clear about the human being we want to build.

In this article was presented the work of psychologists in training teachers; however this intervention may be broader, at the institutional level, thus contributing to develop guidelines for university education, for example, or further expanding the work in order to collaborate in drawing up of educational policies. As discussed along the study, the challenge that lies ahead is huge. 


\section{A atuação do psicólogo escolar no Ensino Superior e a formação de professores}

Resumo: Este artigo tem como objetivo discorrer sobre aspectos que envolvem a atuação do psicólogo no âmbito do Ensino Superior, partindo dos pressupostos da Psicologia Histórico-Cultural. Destacamos a possibilidade de atuação do psicólogo escolar na formação de professores nesse nível de ensino, vislumbrando a sua contribuição para que o docente possa entender acerca da relação desenvolvimento e aprendizagem de adultos, com ênfase na formação dos conceitos. Apresentamos também os resultados de entrevistas realizadas com 20 professores de uma IES, em 2009, que buscaram analisar a compreensão dos mesmos sobre a relação desenvolvimento e aprendizagem e trabalho do psicólogo escolar. Concluindo, consideramos que a proposta de uma intervenção da Psicologia na formação de professores pode contribuir para que os docentes compreendam o quanto o desenvolvimento psicológico é ilimitado e como a atividade pedagógica, na transmissão e apropriação dos conhecimentos, pode levar o aluno a um maior desenvolvimento da sua capacidade intelectual.

Palavras-chave: Atuação do psicólogo escolar. Ensino Superior. Formação de professores. Psicologia Histórico-Cultural.

\section{La performance du psychologue scolaire dans l'enseignement superieur et la formation de professeurs}

Résumé: Cet article a le but à discourir sur les aspects que s'engage la permance du psychologue dans l'ambiance du l'ensegnement superieur, à partir des présuppostes de la psychologie Historique-Cultural.Nous détachons la possibilité de performance du psycologue scoleire dans la formation de professeurs dans ce niveu d'enseignement en entrevoint leur contribution pour les enseignants peuvent comprendre sur la relation développement et l'apprentissage des adults, avec emphase sur la formation de concepts. Nous présentons les résultats des entretiens, avec 20 enseignants accompli à partir d'une IES en 2009, qui visait à analyser la compréhension même de l'établissement de relations et de l'apprentissage et le travail du psychologue de l'école. En conclusion, nous considérons que la propose d'une intervention de psychologie dans la formation des professeurs peut contribue pour enseignants comprendre combien le séveloppement Psychologique est ilimité et comment l'activité pedadogique, dans la transmission et acquisition de la connaissance, peut mener les élèves à un plus grand développement de leur capacité intelectuel.

Mots-clés: Performance du psycologue scolaire. Ensegnement superieur. Formation de professeurs. Psychologie Historique-Cultural. 


\section{La actuación del psicólogo escolar en la Enseñanza Superior y la formación de profesores}

Resumen: Este articulo tiene como objetivos argumentar sobre aspectos que envuelven la actuación del psicólogo en el ámbito de la Enseñanza Superior, a partir de los presupuesto de la Psicología Histórico-Cultural. Destacamos la posibilidad de actuación del psicólogo escolar en la formación de profesores en este nivel de la enseñanza, vislumbrando su contribución para que el docente pueda entender acerca de los conceptos. Presentamos también los resultados de entrevistas realizadas con 20 profesores de una IES, en 2009, que buscaron analizar la comprensión de los mismos sobre la relación desarrollo y aprendizaje y trabajo del psicólogo escolar. Concluyendo, considerando que la propuesta de una intervención de la Psicología en la formación de profesores puede contribuir para que los docentes comprendan lo cuanto el desarrollo psicológico no tiene límites y como la actividad pedagógica, en la transmisión y apropiación de los conocimientos, puede llevar el alumno a un mayor desarrollo de su capacidad intelectual.

Palabras-clave: Actuación del psicólogo escolar. Enseñanza Superior. Formación de profesores. Psicología Histórico-Cultural. 


\section{References}

Basso, I. S. (1998, abril). Significado e sentido do trabalho docente. Caderno Cedes, 19(44), 19-32.

Checchia, A. K. A., \& Souza, M. P. R. (2003). Queixa escolar e atuação profissional: apontamentos para a formação de psicólogos. In M. E. M. Meira \& M. A. M. Antunes (Orgs.), Psicologia escolar: teorias críticas (pp. 105-138). São Paulo: Casa do Psicólogo.

Dal Castel, M. C. (2007). Docência na educação superior: subsídios expressos nas discussões de três GTS da ANPED acerca da formação de professores e da prática pedagógica. Dissertação de Mestrado, Programa de Pós-Graduação em Educação, Universidade Estadual de Maringá, PR.

Davidov, V., \& Markova, A. (1987). El desarrollo del pensamiento en la edad escolar. In V. Davidov \& M. Shuare (Orgs.), La psicologia evolutiva y pedagógica en la URSS Antologia (pp. 173-193). Moscou: Progresso.

Engels, F. (1990). O papel do trabalho na transformação do macaco em homem. São Paulo: Global.

Facci, M. G. D. (2004a). Valorização ou esvaziamento do trabalho do professor? Um estudo crítico-comparativo da teoria do professor reflexivo, do construtivismo e da psicologia vigotskiana. Campinas, SP: Autores Associados.

Facci, M. G. D. (2004b). Teorias educacionais e teorias psicológicas: em busca de uma psicologia marxista da educação. In N. Duarte (Org.), Crítica ao fetichismo da individualidade (pp. 99-120). Campinas, SP: Autores Associados.

Facci, M. G. D. (2009). A intervenção do psicólogo na formação de professores: contribuições da psicologia histórico-cultural. In C. J. Marinho-Araújo (Org.), Psicologia escolar: novos cenários e contextos de pesquisa, formação e prática (pp. 107-131). Campinas, SP: Alínea.

Lei no. 9.394, de 20 de dezembro de 1996. (1996). Estabelece as Diretrizes e Bases da Educação Nacional (LDB). Recuperado em 30 de outubro de 2009, de http:// www.planalto.gov.br/ccivil_03/Leis/L9394.htm

Leontiev, A. N. (1978). O desenvolvimento do psiquismo. Lisboa: Livros horizonte.

Leontiev, A., Luria, A. R., \& Vigotsky, L. S. (1991). Psicologia e pedagogia: bases psicológicas da aprendizagem e do desenvolvimento. São Paulo: Moraes. 
Luria, A. R. (1990). Desenvolvimento cognitivo: seus fundamentos culturais e sociais. São Paulo: Ícone.

Marinho-Araújo, C. M. (2009). Psicologia escolar na educação superior: novos cenários de intervenção e pesquisa. In C. J. Marinho-Araújo (Org.), Psicologia escolar: novos cenários e contextos de pesquisa, formação e prática (pp. 155-202) Campinas, SP: Alínea.

Martins, L. M. (2007). A formação social da personalidade do professor: um enfoque vigotskiano. Campinas, SP: Autores Associados.

Mazzeu, F. J. C. (1998). Uma proposta metodológica para a formação continuada de professores na perspectiva histórico-social. Cadernos CEDES, 19(44). Recuperado em 30 de outubro de 2009, de http://www.scielo.br/scielo.php?pid=S010132621998000100006\&script=sci_arttext

Meira, M. E. M. (2003). Construindo uma concepção crítica de psicologia escolar: contribuições da pedagogia histórico-crítica e da psicologia sócio-histórica. In M. E. M. Meira \& M. A. M. Antunes (Orgs.), Psicologia escolar: teorias críticas (pp. 13-77). São Paulo: Casa do Psicólogo.

Nuñez, I. B., \& Pacheco, O. G. (1997). La formación de conceptos científicos: una perspectiva desde la teoria de la actividad. Natal: EDUFRN.

Pimenta, S. G., \& Anastasiou, L. G. C. (2005). Docência no ensino superior (2a ed.). São Paulo: Cortez.

Placco, V. M. N. S. (2006). Perspectivas e dimensões da formação e do trabalho do professor. In XIII ENDIPE - Encontro Nacional de Didática e Prática de Ensino. Educação formal e não formal, processos formativos e saberes pedagógicos: desafios para a inclusão social (pp. 251-262). Recife: ENDIPE.

Saviani, D. (1997). A função docente e a produção do conhecimento. In Educação e Filosofia, 11(21/22), 127-140.

Saviani, D. (1999). Da nova LDB ao novo Plano Nacional de Educação: por uma outra política educacional (2a ed.). Campinas, SP: Autores Associados.

Saviani, D.(2003). Pedagogia histórico-crítica: primeiras aproximações (8a ed.). Campinas, SP: Autores Associados.

Tanamachi, E. R., \& Meira, M. E. M. (2003). A atuação do psicólogo como expressão do pensamento crítico em psicologia e educação. In M. E. M. Meira \& M. A. M. 
Antunes (Orgs.), Psicologia escolar: práticas críticas (pp. 11-62). São Paulo: Casa do Psicólogo.

Tolstij, A. (1989). El hombre y la edad. Moscu: Editorial Progreso.

Tuleski, S. C. (2008). Vygotski: a construção de uma psicologia Marxista (2a ed.). Maringá, PR: Eduem.

Vigotski, L. S. (1998). A formação social da mente. São Paulo: Martins Fontes.

Vygotski, L. S. (2000). Obras escogidas III. Madrid: Visor.

Vygotski, L. S. (2001). A construção do pensamento e da linguagem. São Paulo: Martins Fontes.

Vygotski, L. S., \& Luria, A. R. (1996). Estudos sobre a história do comportamento: símios, homem primitivo e criança. Porto Alegre: Artes Médicas. 
Kelly Cristina Zavadski, Professor at Faculdade de Pato Branco - FADEP. Mailing Address:Av.Tupy, 780, ap.02,Bairro Bortot, Pato Branco-PR.CEP:85504-000.E-mail:kelly@ fadep.br.

Marilda Gonçalves Dias Facci, Professor in Universidade Estadual de Maringá - UEM. Mailing Address: Rua Parque do Horto, 124. Jardim Parque do Horto, Maringá-PR. CEP: 87060-285.E-mail:mgdfacci@uem.br

Received: $13 / 06 / 2011$

Accepted:05/07/2012 